\title{
Диляна Денчева
}

Катедра по славянско езикознание

СУ „Свети Климент Охридски”

„Цар Освободител” 15, София

България

lektura@abv.bg

\section{ТУРЦИЗМИТЕ В БЪЛГАРСКИЯ ФОРУМ В КОНТЕКСТА НА ЕТНИЧЕСКИТЕ ПАРТИИ}

Българо-турските езикови отношения имат дълга и сложна история, която започва с поглъщането на държавата България от Османската империя. По време на петвековното османско владичество в българския език проникват множество думи от османския турски език, а чрез неговото посредничество и редица думи от арабски и персийски произход, всички те окачествявани като туриизми в съвременната българска лексикология. В периода на българското Възраждане осъзнаването на езиковата принадлежност е съществен елемент от формирането на българското национално самосъзнание. Процесът на изграждане на книжовния български език започва именно в този период - в него се установяват и кодифицират книжовноезиковите норми, а по отношение на турцизмите се зараждат силни пуристични тенденции. Съзнателното прочистване на езика от турските заемки се засилва още повече след Освобождението, а голяма част от тези, които остават да функционират в българския език, са подложени на силна пейоризация и получават стилистична маркираност. М. Стаменов посочва, че причината за това следва да се търси в процеса на „дисимулация”, т.е. на оттласкване (архаизация) и отбльскване (пейоризация) на българската от османската турска култура [Стаменов 2011: 165]. Според него „семантичното и стиловото „падение" на турцизмите е израз на еднозначната като насока ориентация на носителите на българския език през последните 133 години да се разграничат от османското минало чрез начините на употреба на езика си" [Стаменов 2011: 170]. Силата на процеса е толкова голяма, че същият автор говори за „системна пейоризация в големи мащаби” на турските заемки у нас [Стаменов 2011: 44]. 
В началото на прехода от една политическа система към друга през 90-те години на миналия век турцизмите отново излизат на публичната езикова сцена, възродени от новите, демократични медии. Освободена от клишето и контролираната строгост на социалистическата „правилност”, новата преса отвръща със словесен ,разгул”, пренебрегвайки стиловата кохерентност и сваляйки всякакви изисквания по отношение на книжовноезиковата норма $^{1}$. Подгонени от непреодолимия натиск на пазарното оцеляване, новите вестници напояват текстовете си с турцизми, като с това преследват две цели: както да слязат до речника и на най-непретенциозния читател, така и да го впечатлят с ударна експресивност, било то с цената на откровена ориентализация на речта.

Този процес не се радва на особено дълъг живот. М. Стаменов дори условно го датира: 1991 - 2006, като за начало приема появата на в-к „24 часа", а за край - приемането на България в ЕС [Стаменов 2011: 348]. Фундаменталният труд на БАН „Българска лексикология и фразеология, т. 1” също отбелязва, че силната жаргонизация и профаниране на речта, израз на демократизация в живота и в езика, постепенно отстъпват, като се достига до функционално маргинализиране на турцизмите [Крумова-Цветкова 2013: 158].

В рамките на отбелязаната обща особеност на постсоциалистическия медиен език М. Виденов отбелязва и една частна тенденция: „По обясними причини ориенталските думи стават едва ли не задължителни, когато се говори или се пише за събития, свързани с Движението за права и свободи $(Д П С)^{2}$ - това внася лесно доловим колорит" [Виденов 2013: 522]. Така цитираното изречение на практика се превърна в повод за написването на тази статия. Пьрвоначалната цел беше да се провери доколко тази теза е приложима към днешната езикова картина на българските медии. Тук му е мястото да се отбележи, че ако тезата на М. Виденов обхваща зората на демокрацията у нас, когато в политическия живот присъства само една партия със сравнително еднороден от етническа и религиозна гледна точка електорат, то в момента броят на подобните партии е по-голям. През последните няколко години се появиха две нови политически формации, които могат да се разглеждат като фракции, отцепили се от ДПС: ДОСТ, с председател Лютви Местан (бивш председател на ДПС) и Народна партия „Свобода и достойнство”, учредена от Касим Дал и Корман Исмаилов (също бивши привърженици на ДПС), с председател Орхан Исмаилов. По тази причина темите,

${ }^{1}$ Подобен процес протича и в постсоциалистическа Полша; при него обществено-политическата реч охотно се насища с разговорни елементи като реакция на доминиращата скована и клиширана nowomowa (калка на оруелския израз newspeak).

${ }^{2}$ Движение за права и свободи с тогавашен председател Ахмед Доган и настоящ Мустафа Карадайъ - центристка политическа партия, подкрепяна главно от етническите турци и други мюсюлмани в България. Многократно е обвинявана в противоконституционност заради чл. 11, ал. 4 на Първа глава от Конституцията, според която „не могат да се образуват политически партии на етническа, расова или верска основа". 
свързани по някакъв начин с тези партии, също бяха включени в проучването. Към тях бяха добавени и новинарски съобщения и журналистически анализи, посветени на днешна Турция поради актуалността на политическите събития в южната ни съседка и нарасналата ѝ геополитическа роля. И така, прегледът на съвременни текстове със същата, но разширена тематика показва, че тенденцията, забелязана от М. Виденов, изцяло се подчинява на общия регрес в използването на турските заемки. В един сериозен обем от новинарски текстове с тема ДПС, ДОСТ, НПСД, техните лидери и партийни функционери, както и събитията в днешна Турция, броят на лексикалните заемки от турски език е пренебрежимо малък. Изключение правят ограничен брой заглавия, както и текстовете, които нямат новинарска насоченост, а спадат към колумнистките анализи и традиционно се отличават с емоционалност и подчертана категоричност на личното мнение (напр. рубриката на А. Джамбазки в сайта lentata.com).

Примери:

„Девин или Доган вилает” (в-к „Десант”)

„Доган - патриот на феодалния си вилает” (в-к „Поглед”)

„Доган загуби иял вилает в Североизточна България” (в-к „Сега)

„,404 хиляди ченгета и аскер пазят изборите в Туриия” (в-к Марица”)

„Граждански башибозук в Истанбул” („Гъдел нюз”)

„ГЕРБ, БСП и ДПС пак направиха метан към Анкара за арменския геноцид” (в-к „Атака”).

При прегледа на статиите се очерта общото впечатление, че за разлика от тях, съпътстващите ги коментари изобилстват с турцизми. Това наблюдение генерира една нова теза, която всъщност е предметът на настоящата статия и която провокира събирането на емпиричен материал за доказването, респ. опровергаването ѝ.

От функционално-семантична гледна точка турските заемки в съвременния български език могат да се разпределят в няколко основни групи (представената класификация се опира на изложената в „Българска фразеология и лексикология, т. 1" [Крумова-Цветкова 2013: 153] с незначителни модификации - подреждам ги по степента им на неутралност и разделям остарелите думи от ригидните суперлативи):

1. Неутрална лексика, напълно одомашнена в българския език и загубила чуждия си характер. Това е преди всичко битова лексика, свързана с назоваване на дома, предмети от домашния бит, облеклото, кухнята (чорan, мyса$\kappa a$, леген). Лексемите от тази група нямат еквивалент от български произход.

2. Историзми, свързани с обществената и военната структура на Османската империя, с исляма и с историята на българския народ като население в границите на империята. Използват се в исторически описания, в произведения на художествената литература или филмови сценарии за пресъздаване на историческия колорит на епохата (султан, ходжа, спахия).

3. Остаряла, често простонародна (калевра, ортакльк, бастисвам) лексика. Голяма част от нея е остаряла поради изчезването на денотатите, друга 
продължава да функционира в диалектите, поради което се възприема като простонародна. Характерно за втората подгрупа е, че има еквиваленти в книжовния език, а употребата ѝ води до стилистично снижаване.

4. Силно пейоративна лексика. Много от пейоративите са имена на лица, обикновено назоваващи мъже, и са се утвърдили като обиди, т. нар. хулни думи [Крумова-Цветкова 2013: 156]. М. Стаменов ги нарича ригидни суперлативи, които притежават два признака - първият е този за ригидност, т.е. „не могат да бъдат смекчени чрез добавка на суфикс за диминутив по начина, по който това може да бъде сторено с другите думи в българския език [...]. Вторият признак се заключава в тяхната суперлативност - ако турцизмите са налице в дадена верига от синоними, те по правило (което търпи определени изключения) заемат мястото на най-силно експресивните с оглед на силата на отрицателната конотация, която се свързва с тях.” [Стаменов 2011: 163].

В проучването, посветено на тезата, че определени теми провокират активирането на турцизмите в езика на интернет потребителите, бяха търсени предимно лексеми от втората, третата и четвъртата група; одомашнените турцизми бяха изключени. Бяха прегледани стотици коментари под статии на горепосочените теми във всякакъв тип електронни издания - от новинарски сайтове (някои от които с жълтеникав оттенък) до електронни вестници с традиции и дълго присъствие на пазара (вестниците „24 часа”, „Дневник” и др.), като целта беше да бъдат обхванати както потребителите на кратки новини, така и читателите на по-задълбочени текстове и анализи. По време на работата с медийните текстове се очерта още една тенденция, а именно - в случаи на материали, посветени на мигрантските вълни към Европа, коментиращите също охотно посягат към турцизмите, срв.

И най - важното, ако сега си съществуваше „пролетарската диктатура”, която недолюбваш, в Харманли и по Лъвов мост нямаше да се шетат ябанджии и да плашат орталъка. Границата щеше да е граница, както си беше - непристьпна. Айде, че с аджамии става и скучничко да се говори. Нейсе, любезен човек съм.

Емпиричният материал дава основание да се твърди, че гореизброените теми не само способстват за активизирането на турцизмите в езика на потребителите, нещо повече, в него може да бъде очертана известна системност.

\section{1. Използване на лексеми}

Лексикалният материал позволи да бъде разпределен в шест групи. Абстрахираните типове не са чисти, при някои от тях се наблюдава принадлежност към повече от една група, напр. кьопек е обидна дума, едновременно с това архаизирана, подобен е случаят и с дюнме. Всяка от обособените групи се отличава със своя вътрешна динамика и специфика на употребата. Към всяка група са приведени примери - извадка от емпиричния материал, който поради големия си обем е невъзможно да бъде представен в рамките на статията. В повечето от тях е запазен оригиналният правопис. 
1. Първата лексикална група, която се отличава със системност и сравнително висока честотност, са гореспоменатите историзми - лексеми, които назовават конкретни реалии от живота на Османската империя и които вече нямат денотат в съвременната действителност (с изключение на аскер):

- дльжности и титли от военната и административната йерархия: $a z a$, бей, паша, султан, еничарин, валия;

- елементи от съсловната подялба на ОИ - рая, гяур;

- елементи от админстративната подялба на ОИ - санджак, вилает;

- военни / паравоенни структури - аскер, башибозук, акънджии / акънджишки отряди.

По-голямата част от лексемите в тази група (aza, бей, паша, султан, валия) се отличават с относителна неутралност и устойчивост на буквалното значение. Относителна, защото преобладаващата част от тях са носители на т. нар. етнокултурна мотивация на конотациите - в конкретния случай при някои лексеми по-силни, при други по-слаби, но винаги отрицателни. Употребени в нетипичен контекст, т.е. в обкръжението на съвременни реалии, историзмите ага, бей, паша, султан, валия сменят функционално-семантичната си характеристика. Конкретно ага и бей бяха регистрирани в множество коментари по два основни начина: в съчетание с имената на партийни лидери и функционери от ДПС, ДОСТ и НПСД:

Доган бей, Доган ага, Местан бей, Местан ага, Касим бей, Касим ага, Корман ага

и в съчетание с имената на българи, членуващи в тези партии:

Делян ага, Евгени бей.

Сред коментарите се среща и неперсонализирано назоваване:

аги, агите туркофили, аги и бейове, напр. Защо НСО охранява тези аги и бейове?

Идентична е съдбата и на лексемата валия:

Архонтът ще става и валия (за Слави Бинев, който премина в редиците на ДПС).

Препращането към длъжности и титли от Османската империя изважда на показ историческата враждебност на българина и изгражда опозицията свой - чужд, чрез която потребителят отграничава въпросните партии от останалите политически структури и ги припознава като етнически. В употребата им се съдържа намекът, че тези партии не обслужват националните интереси и са протурски. Съзнателно или несъзнателно, коментиращият активира една от съвременните функции на турцизмите - да назовават негативни явления; нещо повече - използвайки думи от езика на чуждия, коментиращият го идентифицира и се дистанцира от него. На свой ред 
съчетаването на ага, бей и под. с имената на българи подчертава преминаването им на страната на чуждия и профилира семантичния компонент „предателство”.

Категорично, еднозначно и последователно в българския политически форум лексемата султан е отредена за президента на Република Турция Реджеп ТаиП Ердоган. Назовавайки го с титлата на върховния владетел на Османската империя, потребителят изразява своето съмнение в демократичността на турската президентска власт и провижда в приносителя ѝ неоосманистки амбиции за възраждане на политическата и териториалната мощ на ОИ.

За разлика от гореизброените примери, при които конкретни негативни конотации се активират в контекста, лексемата еничар $(u н)$ се отличава със системна метафоричност ${ }^{3}$. Преносната ѝ употреба е отбелязана в РБЕ: 2. прен. Жесток човек, насилник. Есесовските еничари се тренират в покорените от хитлеристите страни. Изследваният емпиричен материал добавя още една сема към преносното значение на еничарин, а именно - предател, слуга на чужди интереси. Пример:

ДПС е етническа партия, обслужвана от българи-еничари. Т. Дончева ${ }^{4}$.

Лексемите рая и гяур съдържат силни отрицателни конотации, които са използвани и в коментарите; подобен е и конотативният заряд на башибозук, както и на акънджии. Що се отнася до санджак, вилает и аскер, за тях може да се каже, че са относително неутрални и се използват или за изграждането на асоциации с Османската империя, или за придаването на местен колорит и достоверност.

Примери:

В нашенския политически филм една друга реч направи особено впечатление.[...] А именно - тази на почетния председател и същински лидер на ДПС Ахмед Доган.На, ,агата“", „пашата“, „султана“ или както там му викат в ,, елита“ " на ДПС и наменските дьонмета, еничари, потурнаци и ибрикчии.

Касим ага, ти си бил по-голям шейтанин и от нас.

ДПС/ДОСТ под предлог че защитават ,европейските иенности“ вече успешно ислямизираха 60\% от българските граждани, докато безмозъчните ни управниии успешно изпъл-

${ }^{3}$ Става дума за метафора от преходен тип - той се разполага между художествената метафора, авторска и уникална по своя характер, и конвенционалната метафора, която е избледняла от употреба и изгубила художествената си стойност. Илюстрира свойството на метафората да генерира полисемия и често намира място в речниците, посочена като преносно значение [Денчева 2015: 71]

${ }^{4}$ Лексемата еничарин до такава степен е придобила метафоричното значение 'родоотстьпник', че е регистрирана и сред електората на ДПС: „Ага, тая партия е турска, какви са тези еничари?" по повод голямата власт на Делян Пеевски (https://clubz.bg/15298-v_saraite aga_tazi_partiq_e_turska_kakvi_sa_tiq_enichari)

${ }^{5} \mathrm{C}$ курсив са отбелязани не само турцизмите, които спадат към конкретната група, но и всички останали. Целта е да се експлицира наситеността с турски заемки на изказванията. 
няваха ролята на рая и се надпреварваха да им слугуват! някой от тези продажни еничари ще преброи ли в момента колко иъркви имаме в турция /2 или 3/, а само за 25 г. турската държава чрез министерството на исляма построи над 3700 джамии у нас ! къде е принципът на реципрочност ?! а неговият чорбаджия - ислямистът ердоган поиска от властите на куба да му разрешат да строи и там джамии, но отговорът е - само ако куба построи католическа църква със същите размери в туриия! На фона на ксенофобските крясъии на лютви местан /а всъщност ШЕЙТАН/ има ли читав журналист у нас, който поиска коментара му за ислямския тероризъм?

Докато сме мързеливи и заспали, еничари като Бинев, Барекофф, Сидеров и иялото БКП-БСП ще са на власт.

Гюленисти! Заплаха за Туриия! Султанът така реши и така отсъди! Да живее Султанът и неговият шариат!

Пък и днеска му наритаха аскера в Сирия.

Харесвам Бай Ердо. Той е истинската ми надежда измислената територия Туриия най-после да се разпадне на три: европейска, анкарски санджак и Кюрдистан.

Случилото се в НДК е по-скоро шамар за службите по сигурността, които [...] безпомощно допуснаха срамния линч, на който бе подложен поваленият нападател от развилнелия се около сиената делегатски башибозук.

Доста долна лъжа е, че башибозукът на Ердоган е излязъл да защитава демокращията. Излезе, след като ходжите завиха и призоваха за джихад срещу неверниците, а султанът се обади по скайп за същото.

На българска територия, в ролята на акънджишки отряди, действат брадатите майки с деца, наречени от нашенските клакьори ,,клети бежанции “, на втора линия изпратените от Ердоган емисари, превзели българското Главно мюфтийство, на трета линия трите турски партии в България. В последните дни те се надпреварват да докажат коленопреклонност и раболепие пред кандидат-султана.

За думите на Къльчдароглу относно султанската република ли говорите?

Доган е наясно, че в България е голям турчин, а в Туриия би бил прост гяур.

\section{2. Лексика, свързана с бита и ежедневието:}

- части от облеклото: фес, шалвари, чалма;

- предмети от домашния бит: софра, бохча, ибрик, чаршаф;

- лица, предмети и абстрактни понятия, изразяващи семейни и социални отношения: ханъма, кадъна, комшия, армаган, аркадаш, хаир;

- архитектурни типове: зандан, сараи;

- напитки: кайве, шербет.

Фесъm, чалмата и шалварите имат устойчива функция в българския политически форум - метонимично назовават лица от турски произход или мюсюлманите изобщо и могат да бъдат причислени към обидните думи. С напълно одомашнената дума чариаф, която няма роден еквивалент в българския език и респ. никакви отрицателни конотации, системно (и метафорично) се назовават лица от арабски произход, а държавите от арабския свят съответно се срещат като чаршафени републики. Истинска кариера във форумите обаче правят думите ибрик и ибрикчия. Категорично можем да говорим за устойчива метафора със значение 'слуга'. Утвърдено е и значението на лексемата сараи като местообиталище, резиденция на партийните лидери (особено на Доган), която се характеризира със силна отрицателна конотация, свързана с богатството и меркантилността на обитателите ѝ. Самият 
Лютви Местан използва тази дума при поздравяването на новоизбрания президент Румен Радев (Честити сараи, генерале!), намеквайки, че победата му се дължи донякъде и на електората на ДПС.

Известна системност бе забелязана и при употребата на напитките кайве и шербет. В няколко коментара те бяха употребени в контекст на политически разговори, сътрудничество и партийно съглашателство.

Употребата на по-голямата част от останалите лексеми от тази група (бохча, софра, зандан, комшия, ханъма, кадъна, армаган, аркадам) има за цел да постигне кохерентност между темата и езика, използван за коментирането ѝ, да придаде автентичност на събитията или отново, чрез турцизмите да идентифицира другия.

Примери:

Ти бе, недодялан фес [...] защчо не носи информащия от агите за нас (отнася се за Лютви Местан).

Местанчо, [...] пък и на ивят не го докарваш на фес.

Нека и белите [...] да видят какво значат гаджали, иалвари и чалми.

На тия чалми сме им яли попарата 500 години.

Или приемат християнството или в Сауди Арабия при другите чаршафи.

Политически номад - от танковете до шалварите (за Евгени Михайлов).

Турски шпионин и треторазряден американски ибрик (за Лютви Местан).

Тази снимка казва всичко. На нея ясно личи кой е султанът и кой слугата с ибрика (снимка на Ердоган и Лютви Местан).

Евгени явно ще бъде ибрикчия на баш ибрикчията Ердоганов. Келепирец, масраф, ай сиктир.

Машала, либералстващзи ибрици и аферим.

И ся вече кво, дадоха му нови напътствия комшиите и вече не го е страх, така ли? Смех... Местане, Местане, помним как говореше само на турски на всички предизборни митинги, как викаше туриите да дойдат в България. Тия лакърдии за Масква си ги разправяй на некой друг, дето гледа „великолепния век“. Тук могат да ти иъкат и плюсчета, но като политик си вече бита карта. Анадънму...

Ако имаме акъл, щеше да изчака ден-два първо на запад да се обади някой по-загубен лийберален атлантик, вместо сега бягайки попарен от сараите да си организира сигурността на пейката пред чуждо посолство, на което вече не е нужен.

Е какъв е проблема, след като двамиата, на кайве - домакин Местаня (-), съставиха кабинета на Бостаня???

А може да ти се е разляло кайвето, дето отново пиете с Бойче?

Предател премиер - вместо с танкове / ги среща с „бир кайве”. (,Байгън кайве”)

Опатканите се събират на шербетче, за да си оплачат съдбите и да оплюят враговете си, досущ като в турска сапунка по бтв.

Жалка креатура, която при първата по-сериозна трудност тича с жената, децата и бохчата в турското посолство да търси закрила.

Спечелихте изборите в Сърница с вашите армагани (Валери Симеонов към ДПС).

Верно казва аркадаша... ние от юруи - ДПС 2 стоим твърдо зад Доган ага и сме единни във финансирането.

[...] Един откровено казано предател с турско самосъзнание и радикални ислямски възгледи съсипа Коледата на милиони българи и вместо да е вече в зандана [...]продължава да си показва мазната мутра по медиите и отказва да говори на български.

Аферим, ханъм Петя, ясно как си влязла в партията на Доган ефенди [...]. 
3. Лексика, свързана с етикета на общуването:

- обрыщения: ефенди;

- жестове: метан, темане.

Съдбата на лексемата ефенди, изразяваща почтителност, е сходна с тази на ага, бей, валия и под. - пренесена на съвременна почва тя служи за идентификация на (вече) чуждите и за изразяване на отношение към тях. Метан и темане нямат отрицателни конотации, по-скоро функционират в парадигмата на идентификацията на другостта и тематично-езиковата кохерентност.

Доган ефенди, Слави ефенди, Ашколсун, ефенди (обрьщение към Слави Бинев)

Сори, ефендимис, но не може да се окаже по-учен от мен.

Местан с метан пред Ердоган.

Освен това бай Местан използва прекрасен момент за темане пред Анкара.

Това е волята на суверена и на Местан му остава единствено да направи темане.

4. Ригидни суперлативи

- обидни (хулни) думи, обикновено назоваващи лица: абдал, дюнме (във форумите дьонме), будала, гьонсурат, мекере, аланкоолу, деребей / дерибей (с дериват деребействам);

- абстрактни съществителни: далавера, келепир ${ }^{7}$, табиет, гьонсурат-

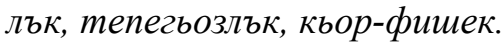

Тази група е напълно монолитна по отношение на пейоративността на лексемите в нея - всичките функционират като емоционално-афективни думи със силна експресия на негативно отношение и враждебност.

Примери:

Хъммм... Местанщина на 100\% /демек гьонсуратльк/.

Абе другар, ти хората хептен за абдали ги взе, бе.

А бе ей, аланкоолу...квопекчи, ти, ако не си взе вярата от Мохамед, от каква мюсла си я взе бе?

Това, казано от теб звучи двусмислено, както сте известни с вашите турски табиети.

Зам. министърът на отбраната (за Орхан Исмаилов) към българската армия: Юруш, аскер, юруш, бе, серсеми!

Да подкрепим Местан щее е изключително трудно. Ще ни изкарат турски ипиони. Мекерета, ибрикчии.

Не ми е другар, както и баща му. Просто мразя дьонмета от всички разновидности.

5. Междуметия, апели и модализатори : вай, машалла / мамала / машаллах, аферим, ашколсун, анджък, юруш, джанъм, чоджум, хеле.

Примери (голяма част от тях се съдържат в горните примери):

Вай, вай, чок проблем!

\footnotetext{
${ }^{6}$ Към тях си позволявам да причисля и абстрактните пейоративи.

7 Лексемите далавера и келепир са силно пейоративни, но правят изключение от правилото за ригидност, напр. далаверка, келепирец. Образуването на форми за диминутив обаче само засилва степента на стилистична сниженост.

${ }^{8}$ Според класификацията на Р. Ласковски, която в случая смятам за по-уместна [Grzegorczykowa 1999: 57].
} 
6. Слабо познати думи, напълно архаизирани: кьопек, чабук, чок, домуз, амуджа.

В тази група се съдържат думи, които не са широко известни, а някои от тях дори липсват в „Речника на турцизмите в българския език”, напр. кьопек и домуз.

Я па го и тоя. Абе ей, амуджолар, кой те спира да се чувстваш див анадолец??

Бря! Доган ефенди нали обещза на електората си вместо тутуна 15000 биволи да им докара, а сега им дава само домуз.

Предатели долни! Ач кьопещи!

\section{2. Словообразуване}

Употребата на турски заемки във форумите не се свежда само до лексеми - емпиричният материал даде множество примери за словоотворчество на коментиращите чрез:

- заемане на оглу - турска наставка за образуване на фамилни имена;

- използване на баш във функцията на префиксоид;

- създаване на сложни думи с компонент -стан по образец на наименованията на държави.

Създавайки имената Първаноглу, Биневогу, Доганоглу, на практика форумният творец укоризнено посочва с пръст ,родоостьпниците” Първанов, Бинев, Доган и ги идентифицира като част от чуждите.

М. Стаменов посочва, че в българската преса се възприема западният образец за изразяване на „елитен, престижен, върхов” с помощта на префиксоида топ-, напр. топдизайнер, топмодел, но на местно, балканско ниво се профанира чрез турската съответка на тол - баш. Още по-интересна е метаморфозата на същия модел, когато вместо ироничното баш се сложи злорадото пишман [Стаменов 2011: 354]. Модельт не подминава и форумното словотворчество:

Ми да, дори по продажническите ни тв-та чат-пат се прокрадваше кви ги върии баш султана.

И мисли, че това ще го направи по-ценен в очите на пишман-султана.

Този 16 април ще е исторически за Ататюркието. Идва краят на кратката, разгромна и полезна за Европата държавииа Ердостан. Очаквам да се сбръчка до анкарския санджак и Ердо да е аятолах.

Актуални новини от евроатлантическия халифатски катун Германистан 9 .

${ }^{9}$ Конкретно този тип словотворчество не подминава и другите езици, срв. Belgistan tykająa bomba w sercu Europy; Welcome to Belgistan; Европастан - о тихой исламизации Евponbl. 


\section{3. Иновативна употреба на устойчиви конструкции}

Форумното езиково творчество намира изява и в създаването на редица иновации:

- фразеологична иновация:

Само дето не съм съгласен, че това в Туриия е „бял кахър”. БАШ КАРА КАХЬР си е.

Наблюдаваме фразеологичната иновация ,замяна на компонент” при която оригиналният компонент бял е заменен с антонимния турцизъм кара (черен). Налице е и фразеологичната иновация „добавяне на компонент”, в случая на баш.

- паремична иновация:

Който плаща гранта, той поръчва кючека.

В ролята на първообраз разпознаваме пословицата Който плащуа, той поръчва музиката. Иновацията се състои в добавката грант и в замяната на компонента музика с турцизма кючек, който стеснява и прецизира значениеTo.

- Иновативна употреба на крилата фраза:

О, неразумний ага, поради щуо се срамиш да се наречеш агент на ДС?

Паисиевото обръщение към българския народ, отдавна превърнало се в крилата фраза, е употребено иновативно, като оригиналните елементи юроде и българин са заменени с турцизма ага и фразата агент на ДС.

\section{4. Стилизация на изречения}

На места сред коментарите се срещат цели изречения, стилизирани чрез употребата на максимален брой турцизми. Свободата на тази стилизация понякога достига размери, при които смисълът напълно изчезва:

Исках да съм по-точен, ама да лапат бахура от гугъл. Зорлен гюзюллюк олмаз, ако не грема.

А бре, мухабет да става, чальм да има. Акъл бол бре чоджум! Фасул или чорба или пък боб-чорба бре чорбаджи! Коюмджията продава алтъне, дюлгер устата гради дюкяне а пък калайджията калайдисува!!!!!

Призива за гласуване с две думи: ДОСТ - чок гюзел и машала. Чабук, чабук към урните, за да има хаир. 


\section{Изводи}

При коментирането на теми, свързани с партиите ДПС, ДОСТ, НПСД и техните функционери, както и със съвременните политически процеси в Турция и мигрантските вълни, се наблюдава засилена употреба на турцизми. Основните цели, които тази употреба преследва, са:

- идентификация на чуждия;

- характеризиране на чуждия;

- дистанциране;

- демонстрация на отношение;

- придаване на езикова достоверност и автентичност на обсъжданите обекти.

Ако в общия процес на културна дисимулация се наблюдава изхвърляне на турцизмите, в случая се наблюдава обратният похват - чрез употребата на турски заемки се подчертава културната отчужденост и дистанцираност на говорещия. Насищането на потребителското изказване с турцизми дори може да се третира като подигравателна имитация на чуждия говор. Конкретно, с изпращането на горепосочените партии в полето на езиковата другост се демонстрира негативно отношение към политическата сепарация на етно-религиозните общества.

С употребата на принизяващи стила езикови средства се постига и принизяване на обществената, културната и моралната стойност на обектите на коментара. Често съзнателно се изграждат асоциации с Османската империя, а съвременните обекти се обременяват с нейното негативно наследство.

Очертаният проблем е не само лингвистичен, но има и културологични измерения.

Има основания за генерирането на теза, според която представителите на българските патриотични и националистически формации проявяват по-изразена склонност към употреба на турцизми в изложения контекст. За разлика от тях представителите на партии с ясно изразена евроатлантическа ориентация са далеч по-въздържани в боравенето с турски заемки. Това обаче е хипотеза, която изисква отделна разработка и за която са необходими основно аудио-визуални източници на емпиричен материал.

\section{Библиография}

Grzegorczykowa R. (1999), Gramatyka współczesnego języka polskiego. Morfologia, red. R. Grzegorczykowa, R. Laskowski, H. Wróbel, Warszawa.

Виденов М. (2013), Социолингвистични проблеми на прехода в България, [в:] сп. „Български език и литература”, година LV, кн. 6, Изд. „Аз Буки”, София.

Денчева Д. (2015), Метафора и преводимост. Подход на лингвиста, София.

Кръстева В. (2013), Речник на туриизмите в българския език, София.

Българска лексикология и фразеология, том 1 (2013), ред. Е. Пернишка, Л. Крумова-Цветкова, София.

Стаменов М. (2011), Съдбата на туриизмите в българския език и българската култура, София. Речник на българския език - http://ibl.bas.bg/rbe/. 
Diliana Danczewa

\section{WORDS OF TURKISH ORIGIN IN INTERNET FORUMS IN THE CONTEXT OF ETHNIC PARTIES}

\section{(Summary)}

The article presents an interesting linguistic phenomenon from the Bulgarian internet area. The comments under articles, which subjects are Bulgarian political ethnic parties as well as political events in Turkey, contain increased number of words of Turkish origin. They can be classified in several subject groups. Not only lexical means are observed but also word-formation means, such as suffix -оглу (Биневоглу). The users also are authors of different kind of linguistic innovations, such as phrase innovation (бял кахър - баш кара кахър) or proverbial innovation (Който плаща гранта, той поръчва кючека).

Key words: comments, words of Turkish origin, ethnic parties, lexical and word-formation means, innovations. 